\title{
A deterministic and stochastic assessment for exposure and risk of arsenic via ingestion of edible crops
}

\author{
Begum Can-Terzi ${ }^{1} \cdot$ Orhan Gunduz $^{2}$. Sait C. Sofuoglu ${ }^{1}$ (D)
}

Received: 23 January 2019 / Accepted: 17 June 2019 / Published online: 13 July 2019

(C) Springer-Verlag GmbH Germany, part of Springer Nature 2019

\begin{abstract}
Natural arsenic contamination is a critical problem for various places around the world. Simav Plain (Kutahya, Turkey) is one such area that was shown to have natural arsenic contamination in its waters and soils. Arsenic exposure through ingestion of edible crops cultivated in Simav Plain and associated health risks were assessed in this study. To achieve this objective, arsenic levels in 18 crop species were estimated based on measured soil arsenic concentrations. Individual and aggregate noncarcinogenic and carcinogenic risks associated with ingestion of arsenic-contaminated crops were then assessed with scenariobased deterministic point estimates and stochastic population estimates. Monte Carlo simulation was used for the estimation of population health risks. Accordingly, wheat was found as the highest-ranked crop specie for the both types of health risks, followed by tomato and potato, which are three of the most consumed crops in the region. The risk levels estimated in this study were relatively high, indicating consumption of crops grown in the plain may be posing significant health risks even at lowerbound estimates. Consuming wheat, tomato, potato, and their products from uncontaminated sources was found to reduce the aggregate risks up to $88 \%$ implicating the importance of proposing suitable management measures for similar risk-prone areas.
\end{abstract}

Keywords Arsenic $\cdot$ Ingestion exposure $\cdot$ Risk assessment $\cdot$ Edible crops $\cdot$ Simav Plain $\cdot$ Turkey

\section{Introduction}

Arsenic contamination of agronomic crops may result from anthropogenic or natural sources. There are many anthropogenic sources including indirect ones, such as emissions of thermal power plants, industry, and traffic, and direct ones such as arsenic-containing fertilizers and pesticides (Bissen and Frimmel 2003). Some agricultural areas, however, have

Responsible editor: Philippe Garrigues

Electronic supplementary material The online version of this article (https://doi.org/10.1007/s11356-019-05774-y) contains supplementary material, which is available to authorized users.

Orhan Gunduz

orhan.gunduz@deu.edu.tr

Sait C. Sofuoglu

cemilsofuoglu@iyte.edu.tr; saitcemil@iit.edu

1 Department of Environmental Engineering, Izmir Institute of Technology, Gulbahce, Urla, 35430 Izmir, Turkey

2 Department of Environmental Engineering, Dokuz Eylul University, Tinaztepe, 35160 Izmir, Turkey naturally high arsenic levels due to arsenic-containing parental rocks that form the base material of the soil and/or arseniccontaminated surface or subsurface waters that are used for irrigation purposes (Zhu et al. 2008; Singh et al. 2010). Therefore, many countries have limit values for arsenic in agricultural soils such as $3.9 \mathrm{mg} / \mathrm{kg}$ in Thailand (Pollution Control Department of Thailand 2001), $12 \mathrm{mg} / \mathrm{kg}$ dry weight in Canada (Canadian Soil Quality Guidelines 1997), $15 \mathrm{mg} / \mathrm{kg}$ for paddy field soils in Japan (Environmental quality standards for soil pollution n.d.), and $20 \mathrm{mg} / \mathrm{kg}$ dry weight in Turkey (TKKY 2001).

Arsenic concentrations in crops are highly related to the chemical composition of soil as the growth medium and crop genotype. Dahal et al. (2008) found a higher correlation between arsenic concentrations in potato and soil compared with irrigation water. Abiotic and biotic factors affect arsenic speciation in soil, hence arsenic mobility and bioavailability. Among the properties of soil, $\mathrm{pH}$ and Eh value, cation exchange capacity, organic matter content, oxides and hydroxides, temperature and residence time, soil constituents, and microorganisms are the most important factors that affect arsenic availability in soils (Kabata-Pendias and Pendias 2011; Zhang and Selim 2008). Genotypic variations of crops also 
affect trace element accumulation. For instance, leafy vegetables tend to accumulate arsenic more than legumes and root vegetables (Kabata-Pendias and Pendias 2011; Alexander et al. 2006).

Phytotoxicity of arsenic depends on the soil characteristics, arsenic speciation, and plant type. Kabata-Pendias and Pendias (2011) described toxic effects of arsenic in plants as growth reduction, cell plasmolysis, root discoloration, violet coloration due to increased anthocyanin, and leaf wilting. Soils with strong arsenic adsorbents provide a less toxic environment to plants due to adsorption phenomena; hence, arsenic does not transport to plants proportional to soil arsenic concentration (Woolson 1973).

Arsenic exists in soils in four oxidation states: arsenate, arsenite, arsenic, and arsine (Bissen and Frimmel 2003). Generally, arsenate (AsV) and arsenite (AsIII) are the major species in soils (Farooq et al. 2016). Arsenate is dominant in aerobic soils, while arsenite is the leading specie in anaerobic or flooded soils (Bissen and Frimmel 2003; Yoon et al. 2015). Even in crops that had been exposed to arsenate, arsenite is the predominant specie in the cells because it is reduced to arsenite by enzymatic or non-enzymatic reactions (Zhao et al. 2009, 2010). A review article by Zhao et al. (2009) stated that at least $59 \%$ of the arsenate transformed into arsenite in crop species such as barley, rice, tomato, Indian mustard, and cucumber while its transformation to dimethylarsinic acid was limited to a maximum value of $3.7 \%$. Hence, dominant arsenic in the crop cells are inorganic species that pose more danger for human health when ingested.

Arsenic is known to be one of the major causes of human cancers worldwide (ATSDR 2000; WHO 2001). Gunduz et al. (2010) reported that $15.8 \%$ of the deaths in District of Simav are cancer-related, and the largest share among cancer types is gastrointestinal cancer with 40\%. Later, Gunduz et al. (2015, 2017) determined that the cancer-related death rate (mainly due to stomach and bladder cancers) was higher in villages with higher arsenic levels in drinking water supply. Average and maximum arsenic concentrations in groundwater of Simav Plain surface aquifer, from which drinking water is heavily extracted, were $99 \mu \mathrm{g} / \mathrm{L}$ and $562 \mu \mathrm{g} / \mathrm{L}$, respectively, while they were $125 \mu \mathrm{g} / \mathrm{L}$ and $179 \mu \mathrm{g} / \mathrm{L}$, respectively for surface waters (Gunduz et al. 2010), which are at least ten times the limit of $10 \mu \mathrm{g} / \mathrm{L}$ recommended by World Health Organization (WHO 2010) and enforced in Turkey (ITASHY 2005). Soil arsenic concentrations in the plain varied between 18 and $113 \mathrm{mg} / \mathrm{kg}$ dry weight (Gunduz et al. 2012), which are high compared with the average global background concentration of arsenic in surface soils of $6.83 \mathrm{mg} / \mathrm{kg}$ (Kabata-Pendias and Pendias 2011). Hence, we argue that crops grown in the plain are most probably contaminated with arsenic due to contamination in soil, subsurface, and surface waters, and that their consumption may be a major exposure pathway, which has not been studied yet. Based on this premise, this study aimed (1) to estimate the concentrations of arsenic in the crops cultivated in Simav, (2) estimate exposure, and (3) health-risk levels associated with their consumption for Simav population.

\section{Materials and methods}

\section{Study area, soil sampling, and analysis}

Simav is a district of Kutahya province located in mid-western Turkey. It has 168,675 ha total land. Brown forest soils are the main soil type covering an area of 76,950 ha. Non-calcareous brown forest soils follow brown forest soils with an area of 66,796 ha. Alluvial, colluvial, organic, and non-calcareous brown soils and rendzinas are the other soil types in the district (KGOPDEU 2011). The average $\mathrm{pH}$ of the agricultural land of Simav Plain is 7.8 , which signifies slightly alkaline soil. Soil texture of the agricultural land consists of $26.0 \%$ sand, $47.1 \%$ clay, and $26.9 \%$ silt. Total saltiness, organic matter, and $\mathrm{CaCO}_{3}$ are $557.6 \mathrm{mS} / \mathrm{m}, 9.03 \%$ and $8.7 \%$, respectively (Güneș 2010). The annual consumption of chemical fertilizer in Simav was reported to be about 7 tons (KGOPDEU 2016), which includes those used in the whole district including greenhouses warmed with geothermal energy.

Soil arsenic concentrations in Simav plain were measured by Gunduz et al. (2012). Soil samples were collected from 15 sampling points in the plain at 1- and 5-m depths. Collected samples were oven dried at $60{ }^{\circ} \mathrm{C}$ overnight, grinded in a ceramic crucible, and sieved $(180 \mu \mathrm{m}, 80$ mesh ASTM). The samples were extracted with nitric acid and analyzed with an ICP-MS by AcmeLabs, Vancouver, Canada. Method detection limit was $0.5 \mu \mathrm{g} / \mathrm{g}$. Blanks $(n=6)$ were all below the detection limit. Average ( \pm standard deviation) precision was determined to be $1.26 \pm 3.39 \%$ by calculating percent difference in analysis of replicate samples $(n=6)$. Accuracy was determined to be $4.48 \pm 2.87 \%$ by analysis of reference materials (OREAS45PA: $n=6$ and DS8: $n=12$ ). Figure 1 shows the study area and the sampling points. The highest arsenic concentration of the observed range (18 to $113 \mathrm{mg} / \mathrm{kg}$ dry weight) was measured on sampling point 7 (SK-7) at 5-m depth. Arsenic concentrations measured at the first and fifthmeter-depth soil samples are listed in Table 1.

\section{Exposure and risk assessment}

Tomato, wheat, potato, and onion are the most widely cultivated edible crops in Simav Plain (TSI 2016). In addition to these species, bean, cabbage, cauliflower, corn, cucumber, garlic, spinach, and lettuce are also produced in the district with a total production of over 100 tons per year. Eighteen crop species grown in the plain (i.e., bean, broccoli, cabbage, carrot, cauliflower, corn, cucumber, eggplant, garlic, lettuce, 


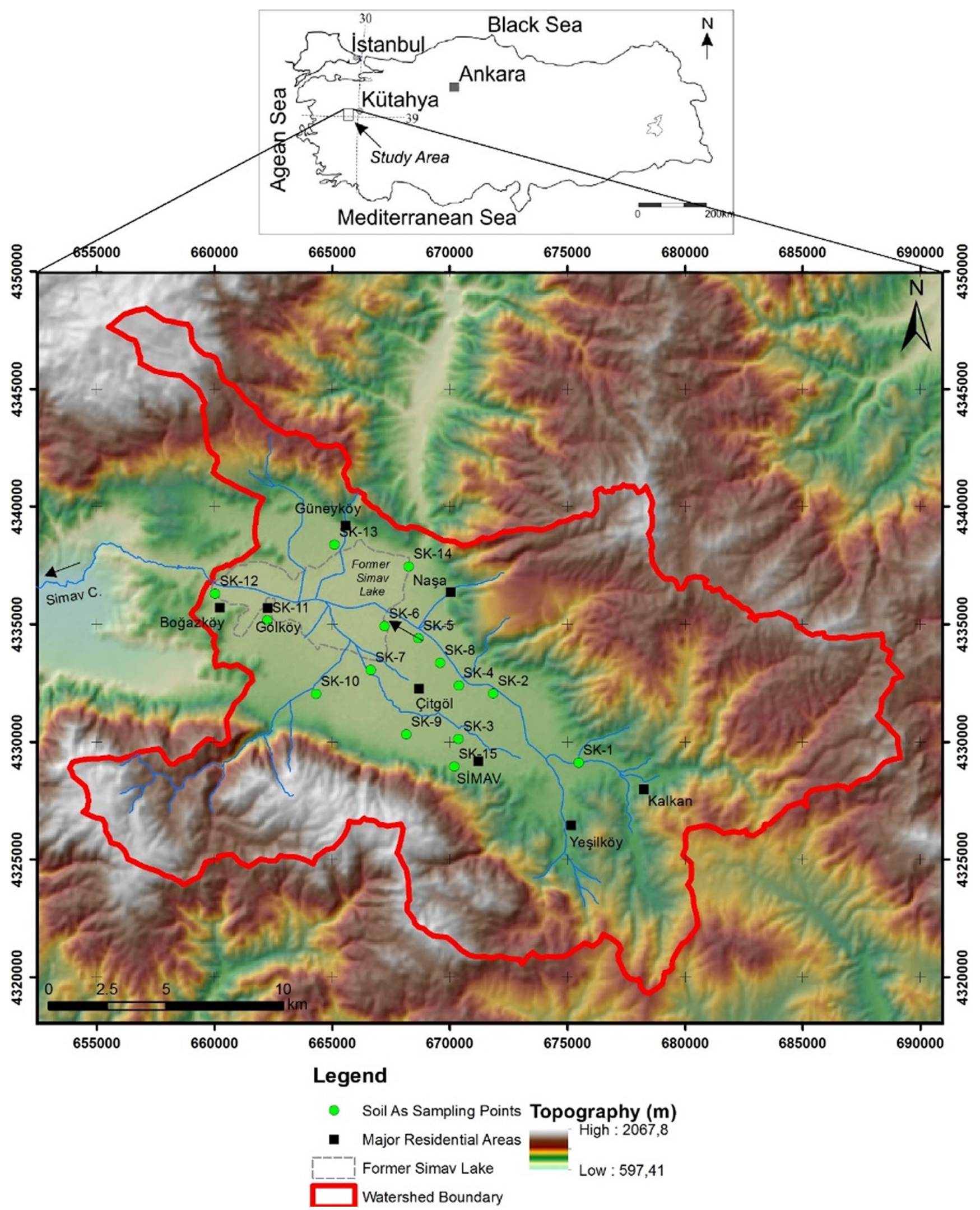

Fig. 1 Study location and soil sampling points (Gunduz et al. 2012) 
Table 1 Measured soil arsenic concentrations at one and five meter depths in the Simav Plain

\begin{tabular}{|c|c|c|c|c|c|c|c|c|c|c|c|c|c|c|c|c|}
\hline \multicolumn{2}{|c|}{ Sampling points } & 1 & 2 & 3 & 4 & 5 & 6 & 7 & 8 & 9 & 10 & 11 & 12 & 13 & 14 & 15 \\
\hline \multirow{2}{*}{$\begin{array}{c}\text { As } \\
\mathrm{mg} / \mathrm{kg}, \\
\text { dry weight }\end{array}$} & $1 \mathrm{~m}$ & 59 & 53 & 36 & 44 & 60 & 71 & 92.5 & 46 & 55 & 29 & 53 & 35 & 56 & 18 & 33 \\
\hline & $5 \mathrm{~m}$ & 46 & 26 & 37 & 45 & 26 & 48 & 113 & 29 & 26 & 58 & 75 & 22 & 37 & 22 & 31 \\
\hline
\end{tabular}

okra, onion, potato, radish, spinach, sunflower, tomato, and wheat) were assessed in this study.

Exposure to arsenic via ingestion of edible crops was estimated by using Eq. 1, modified from Asante-Duah (2002).

$\mathrm{CDI}=\frac{\left[\left(\mathrm{CP}_{\mathrm{z}} \times \mathrm{PIR}_{\mathrm{z}} \times \mathrm{FI}_{\mathrm{z}}\right)+\left(\mathrm{BCP}_{\mathrm{z}} \times \mathrm{PIR}_{\mathrm{z}} \times\left(1-\mathrm{FI}_{\mathrm{z}}\right)\right)\right] \times \mathrm{ABS}_{\mathrm{s}}}{\mathrm{BW}}$

where CDI is chronic daily intake of arsenic from ingestion of crop type $\mathrm{Z}\left(\mathrm{mg} / \mathrm{kg}\right.$-day), $\mathrm{CP}_{\mathrm{Z}}$ is arsenic concentration in the crop from the contaminated source $(\mathrm{mg} / \mathrm{kg}), \mathrm{BCP}_{\mathrm{z}}$ is background arsenic concentration in the crop from uncontaminated sources $(\mathrm{mg} / \mathrm{kg}), \mathrm{FI}_{\mathrm{z}}$ is fraction of the crop ingested from the contaminated source (unitless), $\mathrm{PIR}_{\mathrm{z}}$ is the average consumption rate for the crop (kg-day), $\mathrm{ABS}_{\mathrm{s}}$ is bioavailability (\%), and BW is body weight $(\mathrm{kg})$.

Cancer risk of arsenic exposure via ingestion route is calculated by using Eq. 2, modified from Asante-Duah (2002).

$R=\mathrm{CDI} \times\left(\frac{\mathrm{EF} \times \mathrm{ED}}{\mathrm{AT}}\right) \times \mathrm{SF}$

where $R$ is the probability of lifetime cancer risk (unitless), $\mathrm{CDI}$ is the chronic daily intake of arsenic from ingestion of crop products ( $\mathrm{mg} / \mathrm{kg}$-day), $\mathrm{SF}$ is the slope factor of arsenic $(\mathrm{mg} / \mathrm{kg} \text {-day })^{-1}, \mathrm{EF}$ is exposure frequency (days/years), ED is exposure duration (years), and AT is averaging time defined as the period over which exposure is averaged (days). Exposure frequency was assumed to be 350 days/year by considering an absence of 15 days from the place of residence in a year (USEPA 2011). For carcinogenic risk assessment, average lifetime was assumed as 75 years reported by the World Bank (2017) for Turkey.

Non-carcinogenic risk of arsenic exposure via ingestion route is calculated by using Eq. 3 (Asante-Duah 2002).

$\mathrm{HQ}=\frac{\mathrm{CDI}}{\mathrm{RfD}}$

where HQ is the hazard quotient (unitless) and RfD is the reference dose for oral exposure ( $\mathrm{mg} / \mathrm{kg}$-day).

In this study, the estimated crop arsenic concentrations were conservatively assumed to be inorganic arsenic because inorganic species dominate in the crop tissues (Zhao et al. 2010). Required data for the calculations of chronic daily arsenic intakes were obtained from the literature. The crop consumption rates were obtained from Turkish Statistical
Institute. Exposure Factors Handbook (USEPA 2011) was used for unavailable data from the Institute. The consumption rates used in this study are shown in Table S1 in the supplementary material (SM).

Arsenic concentrations in the edible parts of the crops were estimated by using bioconcentration factor (Eq. 4) values retrieved from the literature and the measured soil arsenic concentrations in Simav Plain. Bioconcentration factor is the ratio of arsenic concentration in the edible parts of the crops to arsenic concentration in soil (Asante-Duah 2002). Web of Knowledge, Google Scholar, and Scopus databases were searched for studies that reported bioconcentration factors for the edible crop species investigated in this study. Only 11 articles were found showing that there are very limited data in the literature about bioconcentration factors. The retrieved values are shown in Table 2.

$C_{\text {crop }}=\mathrm{BCF} \times C_{\text {soil }}$

where $C_{\text {crop }}$ is the arsenic concentration in the edible part of the crop, BCF is the bioconcentration factor, and $C_{\text {soil }}$ is the arsenic concentration of the soil at crop's root depth (see SM, Table S2). The lower-bound value of a general range of 5 to $20 \mathrm{mg} / \mathrm{kg}$ reported as excessive or toxic for plant tissues by Kabata-Pendias and Pendias (2011) was used in this study as the maximum concentration that a crop may contain. Otherwise, the estimated crop arsenic concentrations may reach extreme levels depending on the level of the measured soil concentrations and the available BCF values.

Body weight data for Turkish people (SM, Table S3) were obtained from Turkish Statistical Institute (TSI 2016). The background arsenic concentrations of the edible crops were retrieved from the literature (SM, Table S4). Bioavailability values (fraction of arsenic physiologically available in human body) could be obtained from the literature for only carrot (98\%), radish (77\%), and lettuce (50\%) (Juhasz et al. 2015; Pizarro et al. 2016). Thus, bioavailability was conservatively assumed to be $100 \%$ for the remaining species.

In this study, two methods of exposure-risk estimation were used: deterministic and probabilistic approaches. In the deterministic approach, three main exposure scenarios based on TSI agricultural data were created to assess arsenic risk for people of Simav by considering consumption from (i) crops grown locally in the plain on contaminated land and (ii) crops grown outside the plain on uncontaminated land. For the first main scenario, it was assumed that people who live in Simav 


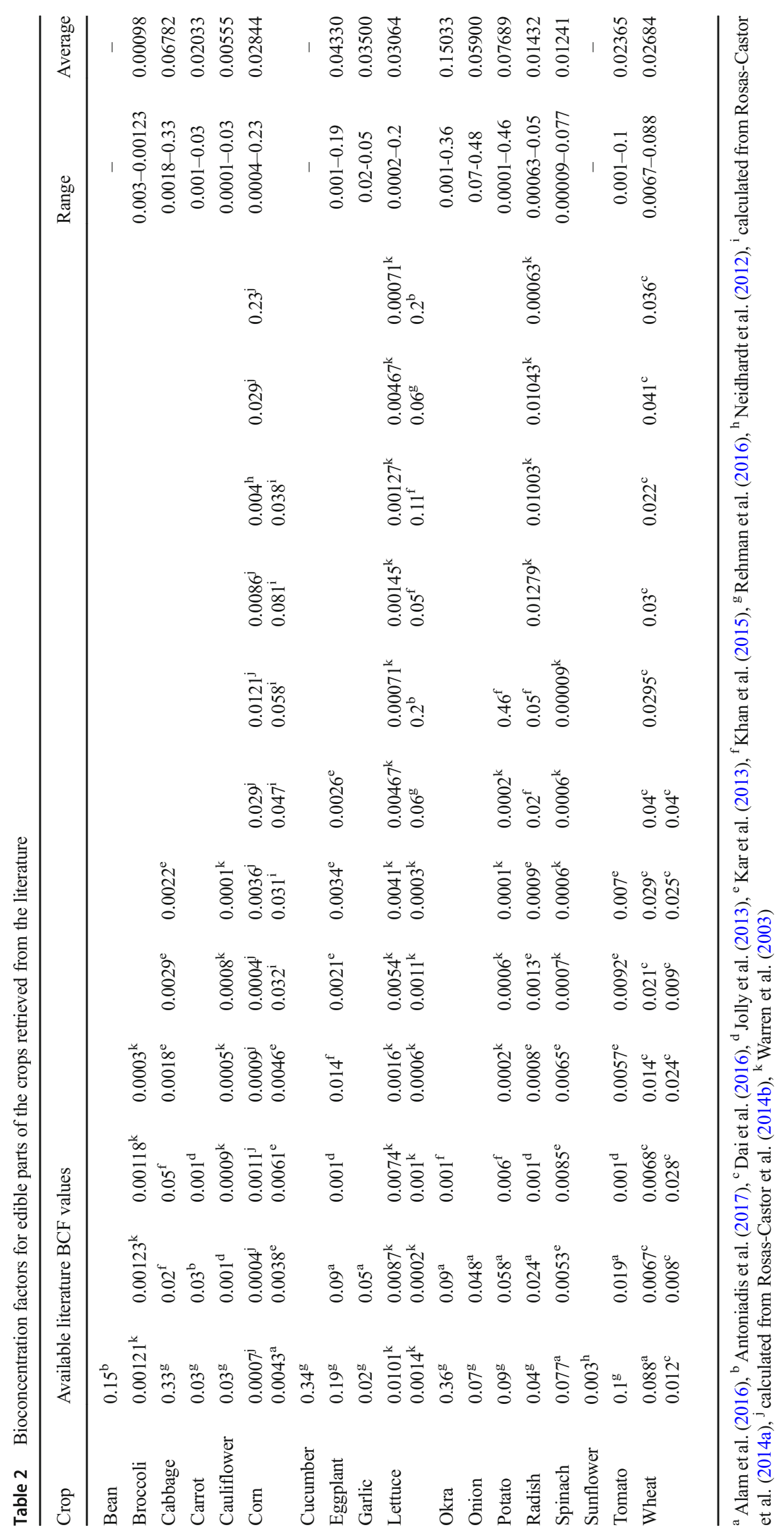


only consume crops produced in the plain as the worst case scenario. The second main scenario was based on $50 \%$ consumption from the local sources and 50\% from the outside sources. The third main scenario assumed that people of Simav supply $90 \%$ of their foodstuff from other places, while local sources comprise the remaining $10 \%$. Three subscenarios (upper-bound, central tendency, and lower-bound estimations) under every main scenario were then composed to reflect the variation in model variables. For the upperbound (UB) estimations, 90th percentile values of the bioconcentration factors, consumption rates, soil and crop concentrations, and 10th percentile value of the body weight were used. Central tendency (CT) estimations express the most likely situation. Fiftieth percentile values of the variables were used in this scenario. For the lower-bound (LB) estimations, 10th percentile values of the bioconcentration factors, consumption rates, soil and crop concentrations, and 90th percentile value of the body weight data were used.

Monte Carlo simulation (MCS) was the applied methodology for probabilistic approach. The random variables in Eq.1 (i.e., bioconcentration factor, consumption rate, soil concentration, background concentration, and exposure duration) were fitted with a probability distribution. The best fitting distribution was selected based on Anderson-Darling and Kolmogorov-Smirnov tests. Consumption rate of crops grown on the contaminated soils, which ranged between 10 and $90 \%$, was also defined as a variable with uniform distribution. Hazard quotient and carcinogenic risk values were defined as forecast values. Each simulation was run for 10,000 trials, creating 10,000 estimations to represent almost all possible scenarios for the population. Their fitted probability distributions, therefore, was assumed to be the distributions of the subject population.

\section{Results and discussion}

\section{Crop arsenic concentrations}

According to deterministic approach, crop arsenic concentrations $\left(\mathrm{CP}_{\mathrm{z}}\right)$ were estimated in a range of $0.01-24 \mathrm{mg} / \mathrm{kg}$ as shown in Fig. 2. Crop concentrations that exceeded $5 \mathrm{mg} / \mathrm{kg}$ were assumed as $5 \mathrm{mg} / \mathrm{kg}$ in health risk assessment calculations due to phytotoxic threshold limit (Kabata-Pendias and Pendias 2011). Figure 2 shows estimated crop arsenic concentrations $\left(\mathrm{CP}_{\mathrm{z}}\right)$ that were used in upper-bound, central tendency, and lower-bound scenarios. The highest arsenic concentrations were calculated for cucumber, okra, and potato while the lowest ones were for cauliflower, sunflower seed, and broccoli. Estimated crop arsenic concentrations varied remarkably in comparison with background arsenic concentrations. Difference between background and estimated arsenic concentrations were as low as within a factor of one to three in the lower-bound scenarios, whereas they were as high as 305 to 860 -folds in the upper-bound scenarios. These variations mainly stem from the variation in BCF values found in the literature (Table 2).

\section{Deterministic exposure-risk estimation}

World Health Organization (WHO) used to recommend a $15 \mu \mathrm{g} / \mathrm{kg}$ body weight for inorganic arsenic as provisional tolerable weekly intake (PTWI) for the assessment of dietary arsenic intake. However, this PTWI value has later been withdrawn. Instead of the withdrawn PTWI, a benchmark dose lower confidence limit ( $3 \mu \mathrm{g} / \mathrm{kg}$-day) for a $0.5 \%$ increased incidence of human lung cancer was suggested by JECFA (2010). For the sake of comparison, $2.1 \mu \mathrm{g} / \mathrm{kg}$-day, which is calculated by dividing PTWI by seven was used in this study as tolerable daily intake limit (TDI) because most of the risk assessments in the literature included the tolerable intake (Núñez et al. 2018; Rasheed et al. 2018; Sofuoglu et al. 2014). As seen in Table 3, estimated chronic daily intake values tend to decrease from Scenario 1 to Scenario 3 owing to decreasing consumption of locally grown foodstuff from contaminated land. The highest CDI values belonged to wheat ranging from $1.64 \times 10^{-3}$ to $2.74 \times 10^{-2} \mathrm{mg} / \mathrm{kg}$-day, which are almost $8-13$ times of the TDI, probably due to its high consumption rate ( $592.8 \mathrm{~g} /$ day on average). The lowest CDI values were observed for broccoli and cauliflower due to low consumption rates ( 6 and $1.9 \mathrm{~g}$ /day respectively). For some of the crops, there were increments in chronic daily intake levels of lower-bound estimates from Scenario 1 to Scenario 3. This is probably due to their high background concentrations relative to the low concentration estimates for lower-bound scenario. Corn, wheat, radish, potato, spinach, eggplant, tomato, and broccoli are the crops that have higher chronic daily intakes for lower-bound estimates from Scenario 1 to Scenario 3. The most prominent example is potato, which has a chronic daily intake in Scenario 3 that is five times that of in Scenario 1. Further elaboration has shown that average background concentration of potato was higher than calculated lowerbound concentration for potato cultivated in contaminated land and the differences in chronic daily intakes have become evident when the consumption ratio of uncontaminated potato increased from Scenario 1 to Scenario 3. The results revealed that the most important factor in the underestimated crop concentrations is the bioconcentration factor. Also, reduction in chronic daily intakes up to 100 times between upper-bound and central tendency estimations is due to heterogeneous distribution of bioconcentration factors, which further highlights its importance. As seen in Table 2, there is considerable variation among the literature-reported bioconcentration factor values, e.g., the maximum to minimum ratio value for potato is 4600 , confirming the need for further research. 


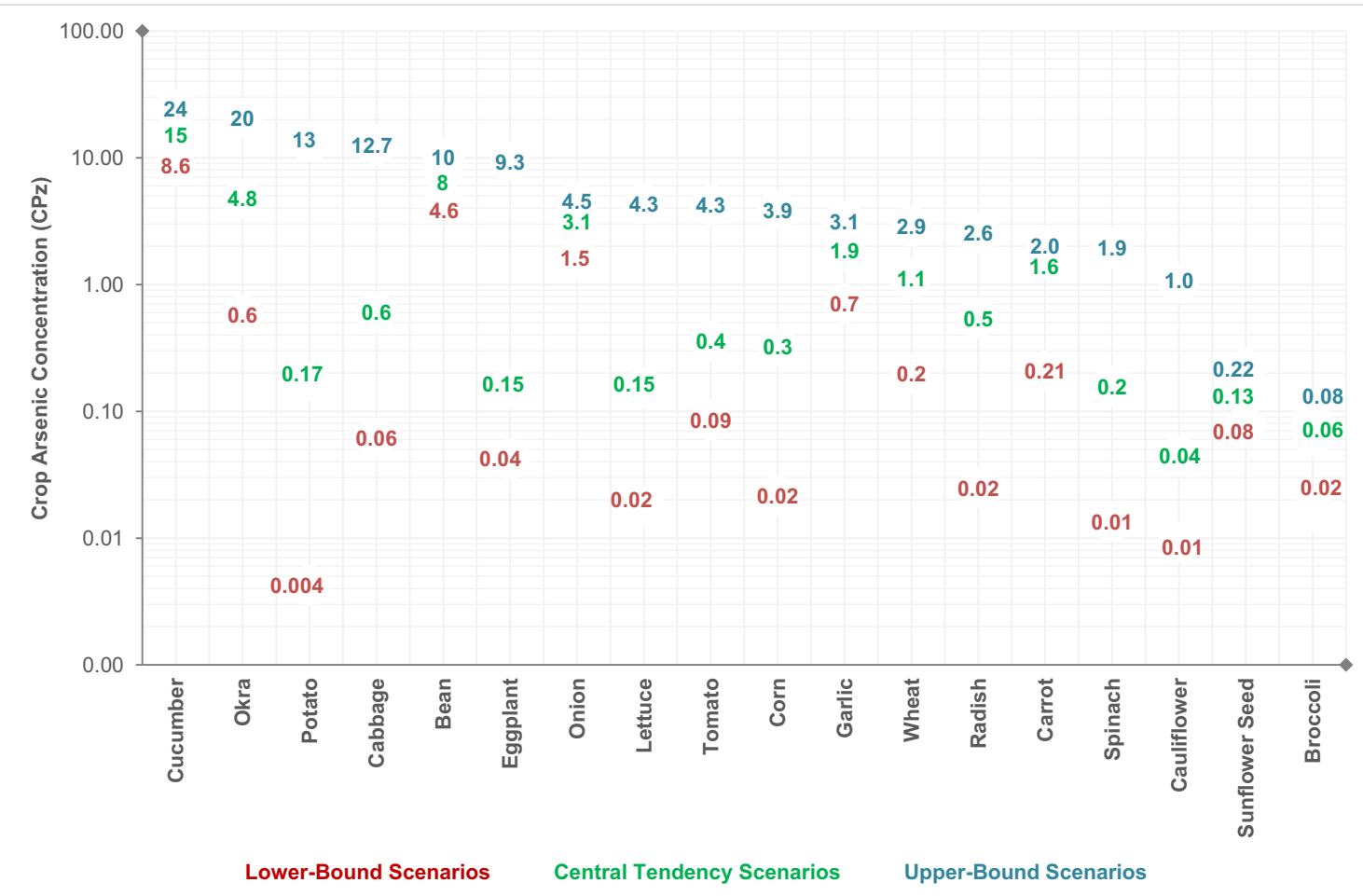

Fig. 2 Estimated crop arsenic concentrations in deterministic approach, $\mathrm{mg} / \mathrm{kg}$

Table 3 Chronic daily intake (CDI) values calculated by deterministic approach, mg/kg-day

\begin{tabular}{|c|c|c|c|c|c|c|c|c|c|}
\hline & \multicolumn{3}{|l|}{ Scenario 1} & \multicolumn{3}{|l|}{ Scenario 2} & \multicolumn{3}{|l|}{ Scenario 3} \\
\hline & UB & $\mathrm{CT}$ & LB & UB & $\mathrm{CT}$ & LB & UB & $\mathrm{CT}$ & LB \\
\hline Corn & $3.44 \times 10^{-3}$ & $1.98 \times 10^{-4}$ & $1.07 \times 10^{-5}$ & $1.73 \times 10^{-3}$ & $1.06 \times 10^{-4}$ & $1.16 \times 10^{-5}$ & $3.64 \times 10^{-4}$ & $3.35 \times 10^{-5}$ & $1.22 \times 10^{-5}$ \\
\hline Lettuce & $4.77 \times 10^{-4}$ & $1.34 \times 10^{-5}$ & $1.31 \times 10^{-6}$ & $2.39 \times 10^{-4}$ & $7.45 \times 10^{-6}$ & $1.29 \times 10^{-6}$ & $4.93 \times 10^{-5}$ & $2.70 \times 10^{-6}$ & $1.27 \times 10^{-6}$ \\
\hline Wheat & $2.74 \times 10^{-2}$ & $8.42 \times 10^{-3}$ & $1.35 \times 10^{-3}$ & $1.50 \times 10^{-2}$ & $5.28 \times 10^{-3}$ & $1.64 \times 10^{-3}$ & $5.14 \times 10^{-3}$ & $2.76 \times 10^{-3}$ & $1.87 \times 10^{-3}$ \\
\hline Radish & $1.82 \times 10^{-4}$ & $3.02 \times 10^{-5}$ & $1.20 \times 10^{-6}$ & $9.26 \times 10^{-5}$ & $1.65 \times 10^{-5}$ & $1.80 \times 10^{-6}$ & $2.13 \times 10^{-5}$ & $5.50 \times 10^{-6}$ & $2.28 \times 10^{-6}$ \\
\hline Potato & $1.32 \times 10^{-2}$ & $3.26 \times 10^{-4}$ & $6.99 \times 10^{-6}$ & $6.65 \times 10^{-3}$ & $1.85 \times 10^{-4}$ & $2.27 \times 10^{-5}$ & $1.38 \times 10^{-3}$ & $7.22 \times 10^{-5}$ & $3.53 \times 10^{-5}$ \\
\hline Spinach & $2.26 \times 10^{-4}$ & $1.49 \times 10^{-5}$ & $1.14 \times 10^{-6}$ & $1.15 \times 10^{-4}$ & $9.02 \times 10^{-6}$ & $1.95 \times 10^{-6}$ & $2.60 \times 10^{-5}$ & $4.28 \times 10^{-6}$ & $2.60 \times 10^{-6}$ \\
\hline Eggplant & $2.54 \times 10^{-3}$ & $5.38 \times 10^{-5}$ & $1.32 \times 10^{-5}$ & $1.32 \times 10^{-3}$ & $6.54 \times 10^{-5}$ & $4.05 \times 10^{-5}$ & $3.52 \times 10^{-4}$ & $7.47 \times 10^{-5}$ & $6.22 \times 10^{-5}$ \\
\hline Cauliflower & $2.98 \times 10^{-5}$ & $1.10 \times 10^{-6}$ & $2.20 \times 10^{-7}$ & $1.50 \times 10^{-5}$ & $6.11 \times 10^{-7}$ & $1.68 \times 10^{-7}$ & $3.11 \times 10^{-6}$ & $2.20 \times 10^{-7}$ & $1.27 \times 10^{-7}$ \\
\hline Cabbage & $1.69 \times 10^{-3}$ & $1.69 \times 10^{-4}$ & $1.51 \times 10^{-5}$ & $8.49 \times 10^{-4}$ & $8.56 \times 10^{-5}$ & $8.56 \times 10^{-6}$ & $1.72 \times 10^{-4}$ & $1.90 \times 10^{-5}$ & $3.36 \times 10^{-6}$ \\
\hline Tomato & $2.11 \times 10^{-2}$ & $1.44 \times 10^{-3}$ & $3.06 \times 10^{-4}$ & $1.08 \times 10^{-2}$ & $9.14 \times 10^{-4}$ & $3.26 \times 10^{-4}$ & $2.55 \times 10^{-3}$ & $4.92 \times 10^{-4}$ & $3.42 \times 10^{-4}$ \\
\hline Broccoli & $7.44 \times 10^{-6}$ & $4.92 \times 10^{-6}$ & $1.21 \times 10^{-6}$ & $4.99 \times 10^{-6}$ & $3.54 \times 10^{-6}$ & $1.64 \times 10^{-6}$ & $3.03 \times 10^{-6}$ & $2.44 \times 10^{-6}$ & $1.99 \times 10^{-6}$ \\
\hline Okra & $9.76 \times 10^{-5}$ & $7.44 \times 10^{-5}$ & $7.44 \times 10^{-6}$ & $4.93 \times 10^{-5}$ & $3.76 \times 10^{-5}$ & $4.05 \times 10^{-6}$ & $1.07 \times 10^{-5}$ & $8.16 \times 10^{-6}$ & $1.33 \times 10^{-6}$ \\
\hline Carrot & $5.92 \times 10^{-4}$ & $3.24 \times 10^{-4}$ & $1.86 \times 10^{-5}$ & $3.00 \times 10^{-4}$ & $1.65 \times 10^{-4}$ & $1.06 \times 10^{-5}$ & $6.70 \times 10^{-5}$ & $3.78 \times 10^{-5}$ & $4.20 \times 10^{-6}$ \\
\hline Onion & $4.85 \times 10^{-3}$ & $2.45 \times 10^{-3}$ & $1.03 \times 10^{-3}$ & $2.47 \times 10^{-3}$ & $1.25 \times 10^{-3}$ & $5.41 \times 10^{-4}$ & $5.62 \times 10^{-4}$ & $3.01 \times 10^{-4}$ & $1.51 \times 10^{-4}$ \\
\hline Garlic & $1.19 \times 10^{-4}$ & $5.61 \times 10^{-5}$ & $1.89 \times 10^{-5}$ & $5.98 \times 10^{-5}$ & $2.83 \times 10^{-5}$ & $9.61 \times 10^{-6}$ & $1.24 \times 10^{-5}$ & $5.98 \times 10^{-6}$ & $2.21 \times 10^{-6}$ \\
\hline Cucumber & $4.45 \times 10^{-3}$ & $3.38 \times 10^{-3}$ & $3.13 \times 10^{-3}$ & $2.24 \times 10^{-3}$ & $1.70 \times 10^{-3}$ & $1.57 \times 10^{-3}$ & $4.67 \times 10^{-4}$ & $3.56 \times 10^{-4}$ & $3.29 \times 10^{-4}$ \\
\hline Sunflower & $2.98 \times 10^{-4}$ & $1.35 \times 10^{-4}$ & $4.49 \times 10^{-5}$ & $1.97 \times 10^{-4}$ & $1.02 \times 10^{-4}$ & $4.28 \times 10^{-5}$ & $1.16 \times 10^{-4}$ & $7.64 \times 10^{-5}$ & $4.11 \times 10^{-5}$ \\
\hline Bean & $6.82 \times 10^{-4}$ & $5.28 \times 10^{-4}$ & $4.43 \times 10^{-4}$ & $3.55 \times 10^{-4}$ & $2.74 \times 10^{-4}$ & $2.31 \times 10^{-4}$ & $9.24 \times 10^{-5}$ & $7.15 \times 10^{-5}$ & $6.13 \times 10^{-5}$ \\
\hline Aggregate & $8.14 \times 10^{-2}$ & $1.76 \times 10^{-2}$ & $6.40 \times 10^{-3}$ & $4.25 \times 10^{-2}$ & $1.02 \times 10^{-2}$ & $4.47 \times 10^{-3}$ & $1.14 \times 10^{-2}$ & $4.33 \times 10^{-3}$ & $2.92 \times 10^{-3}$ \\
\hline
\end{tabular}

$U B$, upper-bound scenario; $C T$, central tendency scenario; $L B$, lower-bound scenario 
Table 4 shows the non-carcinogenic and carcinogenic risks calculated with the deterministic approach. Wheat was found to be the most prominent specie with a non-carcinogenic risk range of 4.5 to 91.2 , which is considerably above the threshold (1.0). Carcinogenic risks of wheat ranged between $1.3 \times 10^{-3}$ and $4.1 \times 10^{-2}$, which are 13 to 410 times higher than the acceptable risk of $10^{-4}$. The background concentrations and bioconcentration factors, which are high compared with the other species, may be responsible for the significantly high carcinogenic risk associated with consumption of wheat. In addition, Turkish people consume relatively high amounts of wheat that is at the center of its daily diet (SM, Table S1). Tomato, potato, onion, and cucumber are the other prominent species that have significant non-carcinogenic and carcinogenic risks. Similar to wheat, these species have relatively high bioconcentration factors and consumption rates compared with the other species. For instance, the average consumption rates of onion and tomato for an average American are 21 and $20 \mathrm{~g} /$ day (USEPA 2011) respectively, while those of Turkish population are 62 and $308 \mathrm{~g} /$ day. Consumption of products such as tomato and wheat may be additionally high because their additional consumption as flour and tomato paste was also included in this study.

The lowest non-carcinogenic risks in the deterministic approach were estimated for lettuce, garlic, spinach, cauliflower, broccoli, okra, garlic, and sunflower seed. Carcinogenic risks associated with their consumption are $>10^{-4}$ only in upperbound Scenarios 1 and 2 except for sunflower seeds with levels ranging from $4.0 \times 10^{-5}$ to $2.9 \times 10^{-4}$ probably because it is consumed as cooking oil. Thus, although not in the unacceptable range, carcinogenic risk levels for these crops still indicate concern.

Aggregate carcinogenic and non-carcinogenic risks were calculated to estimate the total arsenic exposure by consumption of all the studied crops. As expected, the highest noncarcinogenic risk (271) was estimated for upper-bound under Scenario 1. The lowest aggregate non-carcinogenic risk (9.74) was estimated for lower-bound under Scenario 3. Wheat and tomato were the species that constitute $60 \%$ of the aggregate non-carcinogenic risk. It is noteworthy that all of the aggregate non-carcinogenic risks are well above the threshold. The highest carcinogenic risk was estimated for upper-bound under Scenario 1 and the lowest carcinogenic risk was estimated for lower-bound under Scenario 3 as $1.2 \times 10^{-1}$ and $2.9 \times$ $10^{-3}$, respectively, all of which are much greater than the acceptable risk level of $10^{-4}$.

\section{Probabilistic exposure-risk estimation}

In the probabilistic approach, Monte Carlo technique was used to simulate the exposure-risk models. This way, the risk distribution of the subject population can be estimated instead of the point estimates obtained with the deterministic approach.
Figures 3 and 4 show 5 th, 50th, and 95th percentiles of the health risks estimated for the Simavians for non-carcinogenic and carcinogenic risks, respectively. The species with the highest median health risk was found to be wheat, tomato, and potato with about 16,15 , and 14 for non-carcinogenic risk and $4.8 \times 10^{-3}, 4.0 \times 10^{-3}$, and $4.2 \times 10^{-3}$ for carcinogenic risk, respectively. This suggests that tomatoes and potatoes may be as important as wheat, in contrast to the results of deterministic approach. It is also noteworthy that potato has a higher carcinogenic risk than tomato with the probabilistic approach, which was the other way around with the deterministic approach. Aggregate non-carcinogenic and carcinogenic risks reach 68 and $1.95 \times 10^{-2}$, respectively. The probabilistic assessment has shown that risks have skewed distributions with very high upper-bound levels, and they may differ from deterministic point estimates.

A sensitivity analysis was conducted to determine the input variables with the most influence on the output variable, the health risks, by keeping each input variable constant at a time while randomly varying the remaining ones according to their fitted probability distributions. Sensitivity was measured by contribution to the variance. Consumption ratio from contaminated source, background As concentration, consumption rate, soil As concentration, body weight, bioconcentration factor, and exposure duration were examined as input variables in terms of their contribution to variance of the output variable. Bioconcentration factor was found to be the most influential factor on non-carcinogenic risk, followed by consumption ratio from contaminated source while the remaining variables showed noticeable influence for some crops (SM, Table S5). SM, Table S6 shows the results of sensitivity analysis for carcinogenic risk. The most influential variable was again determined to be the bioconcentration factor followed by consumption ratio from contaminated source, which was the most influential parameter for crops with insufficient bioconcentration factor data (bean, cucumber, and sunflower). The remaining variables including exposure duration showed noticeable influence for some crops. Consequently, further data, especially for bioconcentration factor and fraction of consumption from contaminated source, are needed to reduce uncertainty in the estimations.

\section{Comparison with the literature}

The number of studies on the arsenic transfer from soil to crops is limited in the literature. Alam et al. (2016) investigated 25 different crops, and similar to this study, the highest arsenic concentration was found in wheat as $0.21 \mathrm{mg} / \mathrm{kg}$, and arsenic concentrations in the edible parts of the crops ranged between 0.01 and $0.21 \mathrm{mg} / \mathrm{kg}$. Some of the arsenic concentrations in the edible parts of the crops, which were also examined in their study, were found as follows: garlic $0.18 \mathrm{mg} / \mathrm{kg}$, corn $0.13 \mathrm{mg} / \mathrm{kg}$, spinach $0.17 \mathrm{mg} / \mathrm{kg}$, tomato 


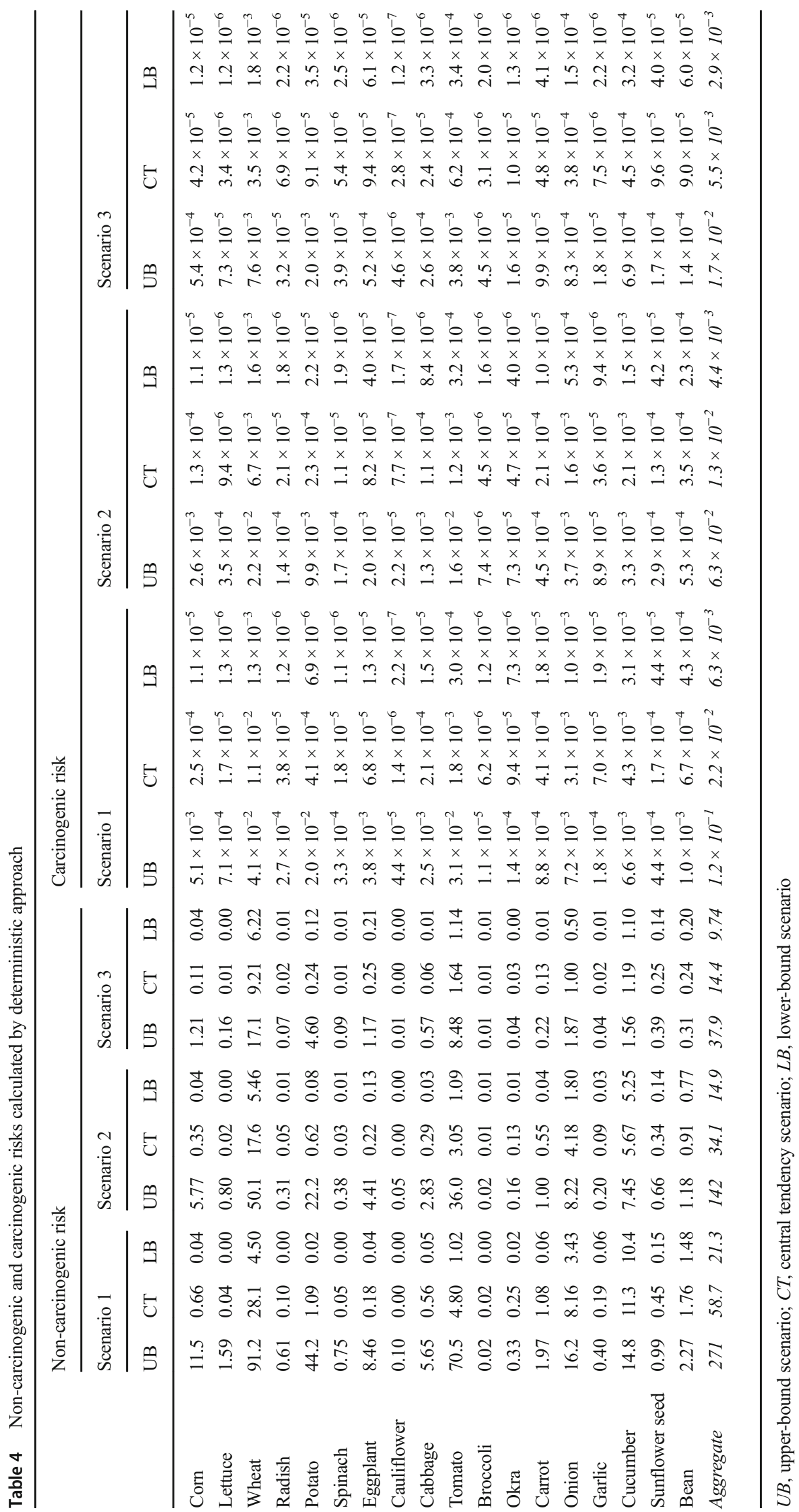




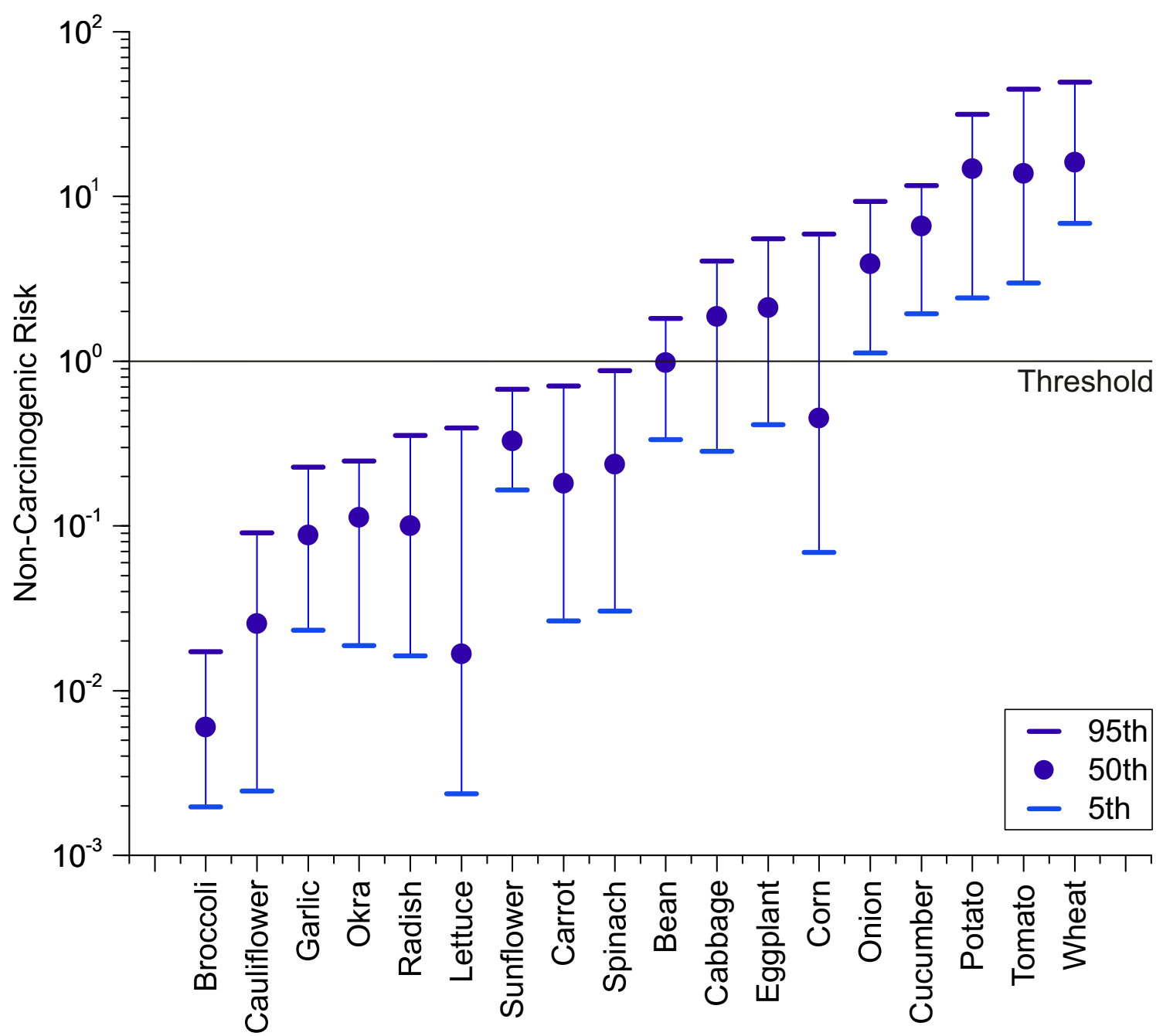

Fig. 3 Population non-carcinogenic risk 5th, 50th, and 95th percentile estimates

$0.05 \mathrm{mg} / \mathrm{kg}$, cucumber $0.10 \mathrm{mg} / \mathrm{kg}$, eggplant $0.12 \mathrm{mg} / \mathrm{kg}$, okra $0.04 \mathrm{mg} / \mathrm{kg}$, potato $0.10 \mathrm{mg} / \mathrm{kg}$, onion $0.07 \mathrm{mg} / \mathrm{kg}$, and radish $0.11 \mathrm{mg} / \mathrm{kg}$. Arsenic concentrations in this study are much higher probably due to insufficient BCF data and lack of knowledge regarding soil arsenic availability for crops. On the other hand, point estimates of non-carcinogenic risk by Alam et al. (2016) are as follows; wheat 2.18, corn 0.53, spinach 0.24 , onion 0.20 , tomato 0.09 , cucumber 0.02 , eggplant 0.06 , okra 0.02 , potato 0.47 , radish 0.03 , and garlic 0.12 , which are very similar to central tendency and lower-bound estimates of this study.

Ahmed et al. (2016) examined wheat, eggplant, bean, potato, tomato, and onion on the account of inorganic arsenic concentrations and estimated daily intake. Inorganic arsenic concentrations ranged between $0.19-$ $0.33 \mathrm{mg} / \mathrm{kg}$, and none of the estimated daily intake values exceeded tolerable daily intake limit $(2.1 \mu \mathrm{g} / \mathrm{kg}$-day $)$. Once again, arsenic concentrations of the crops were much lower compared with the present study. Rehman et al. (2016) deterministically calculated incremental lifetime cancer risk and hazard quotients for eggplant and tomato. The carcinogenic risks for eggplant and tomato were $6.63 \times 10^{-6}$ and $5.10 \times 10^{-5}$, while hazard quotients were 0.01 and 0.11 , respectively. HQs are lower compared with this study probably due to low crop arsenic concentrations, which are $0.13 \mathrm{mg} / \mathrm{kg}$ for tomato and $1 \mathrm{mg} / \mathrm{kg}$ for eggplant. However, the cancer risks for eggplant are on the order of central tendency and lowerbound estimates under all three main scenarios in this study, while they are lower for tomato.

Jiang et al. (2015) have also found lower arsenic concentrations compared with this study with average values of $0.013 \mathrm{mg} / \mathrm{kg}$ for lettuce and cucumber and $0.007 \mathrm{mg} / \mathrm{kg}$ for eggplant and tomato. Crop arsenic concentrations in this study, which are higher than the literature, are based mainly on high soil arsenic concentrations along with large variation in the literature-reported bioconcentration factor values and high consumption rates such as for wheat and tomato.

Gunduz et al. (2010) estimated a carcinogenic risk of $4.95 \times 10^{-3}$ for the average groundwater concentration of the 


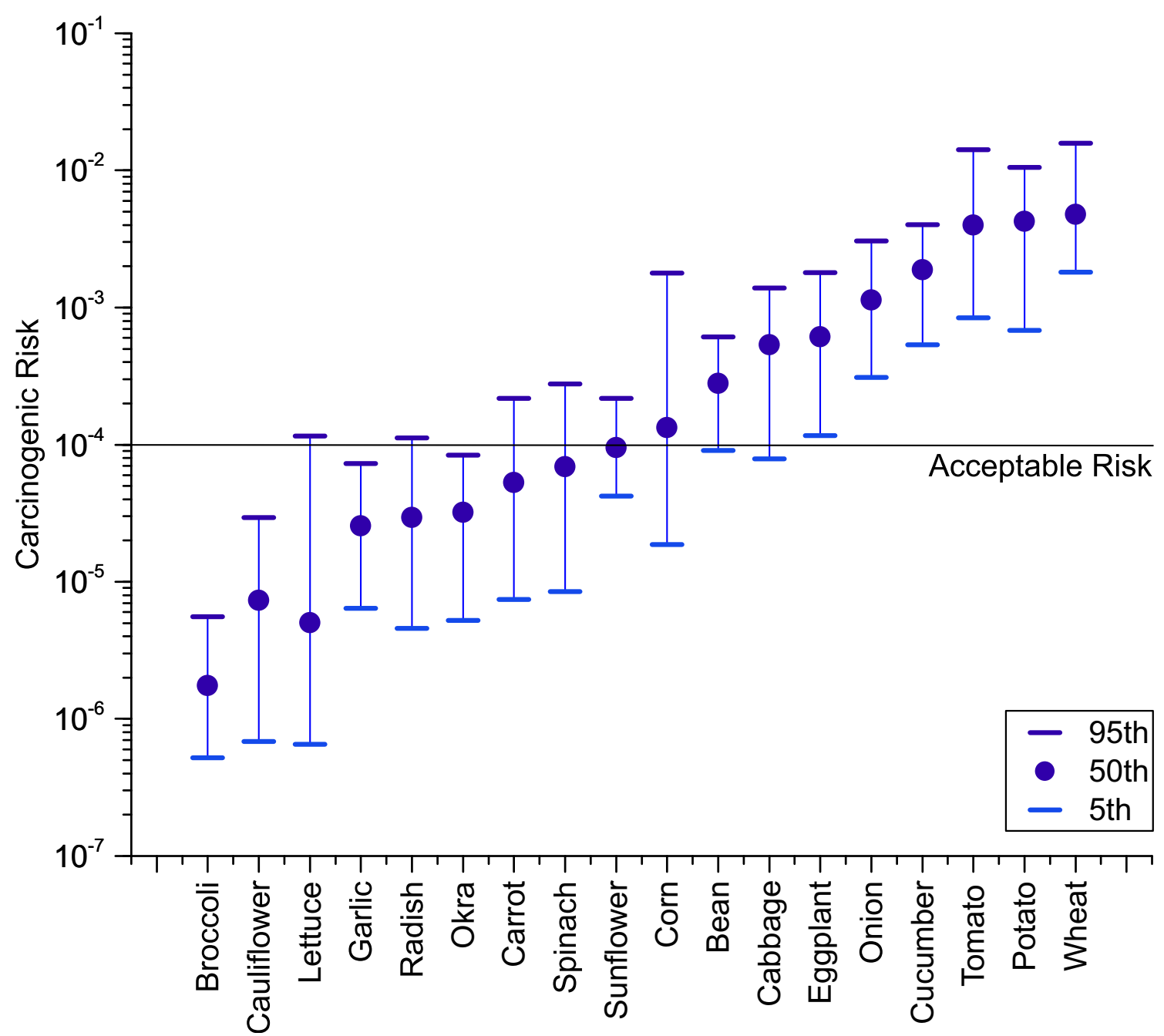

Fig. 4 Population carcinogenic risk 5th, 50th, and 95th percentile estimates

Simav Plain through ingestion of drinking contaminated groundwater. Later, Gunduz et al. $(2015,2017)$ determined that occurrence of bladder, colon, liver, lung, and stomach cancers, and cancer-related death rate were higher in villages with higher arsenic in drinking water supply. Although some of the villages on the plain have switched to other or treated water sources, there is no information regarding the level of contamination and consumption of contaminated crops. Thus, this study complements the missing link with regard to ingestion of arsenic-contaminated crops grown in Simav Plain.

\section{Limitations}

Since the estimations were based on the data collected from the literature except for the measured soil concentrations, there are some limitations to the study. One of the main limitations was scarce bioconcentration factor data for the edible parts of the subject crops. Only eleven journal articles that reported BCF values for the subject crops could be found. The number of identified BCF values in these studies was as low as one (for bean, cucumber, and sunflower), two (for garlic and onion), three (for carrot and okra), and four (for broccoli) while the remainder had at least five. Corn, lettuce, and wheat had the highest number of BCF values ( $n=19,20$, and 21 , respectively). As a result, variability in the calculated arsenic concentrations in the subject crops is limited for some crops due to lack of or limited $\mathrm{BCF}$ data while variation in the available $\mathrm{BCF}$ values resulted in very high edible concentrations for some crops.

The second limitation was the scarcity of specific toxicity data about arsenic on the subject crops. The estimated crop arsenic concentrations may reach extreme levels depending on the level of the measured soil concentrations and the available BCF values, which may not be plausible due to phytotoxicity of arsenic. Therefore, the lower-bound value of a general range (5 
to $20 \mathrm{mg} / \mathrm{kg}$ ) suggested by Kabata-Pendias and Pendias (2011) was used as the maximum concentration that a crop may contain, which may, in any case, be high for some crops resulting in implausible concentrations.

Lack of data about background arsenic concentrations for certain species such as corn, okra, and sunflower seeds was considered to be another limitation of the study. Bioavailability data, which could only be found for three of the eighteen subject species (lettuce, carrot, and radish), resulted in the use of a rather conservative assumption of $100 \%$ bioavailability for the rest of the crops. Furthermore, TSI had a limited consumption database that does not differentiate between the consumption rates of fresh and processed products, which was very important for tomato because its consumption rates as salsa and paste are quite high in Turkish population as fresh produce. Wheat was also an important crop because it is the main subsistence crop for Turkish population that is consumed in various processed forms. Since the consumption rates of tomato and wheat in Turkish population are comparably high (308 and $593 \mathrm{~g} /$ day, respectively), even low concentration levels have translated into unacceptable health risk levels. As a result, tomato and wheat dominated the aggregate risks.

Lastly, the soil concentrations measured by Gunduz et al. (2012) are at the high end of the levels reported in the literature, which probably may be the main factor in estimating such high crop concentrations and health risks associated with their consumption. Also, speciated or water-soluble arsenic concentrations in the soil were not available in the measurements made by Gunduz et al. (2012). Since the crops only absorb the watersoluble arsenic from their roots, it probably caused over estimation of the crop arsenic concentrations along with some high BCF values, conservative speciation, bioavailability, and phytotoxicity assumptions. Processing and cooking the produce may result in leach out of arsenic decreasing the exposure, while it may not occur when the processing/cooking water is also contaminated. The effects of processing and cooking on the exposure concentrations could not be considered in this study. Therefore, the central tendency scenarios in the deterministic approach and median values estimated by the probabilistic approach should be the better estimates for further action such as planning and application of mitigation efforts or for comparison for future studies.

This study originated from the absence of measured concentrations in crops produced on the plain. Therefore, a speciated arsenic concentration survey is absolutely needed along with a survey to determine how much is consumed by the Simavians to conduct an aggregate exposure-risk assessment that would involve much less uncertainty.

\section{Conclusions}

An exposure-risk assessment for ingestion of edible crops cultivated on the contaminated land was conducted for the Simav Plain, where waters and soil are contaminated with arsenic from natural sources. The assessment included both scenario-based point estimates (deterministic approach) and probabilistic population estimates. The edible crops were found as an important source of exposure to arsenic. Central tendency point estimates of non-carcinogenic risk varied from $<0.01$ for cauliflower to 17.6 for wheat with an aggregate value of 34.1. On the other hand, carcinogenic risk levels ranged between $7.7 \times 10^{-7}$ for cauliflower and $6.7 \times 10^{-3}$ for wheat with an aggregate value of $1.3 \times 10^{-2}$. Wheat was found to be the crop associated with the highest health risks followed either by tomato and potato with probabilistic assessment resulting in 50th percentile non-carcinogenic risk values of 16,15 , and 14 , and carcinogenic risk values of $4.8 \times 10^{-3}$, $4.0 \times 10^{-3}$, and $4.2 \times 10^{-3}$ for wheat, tomato, and potato, respectively. Other crops with lower but comparable risk levels were cucumber and onion. High levels of risk are estimated because the measured soil concentrations are high, and there is limited bioconcentration factor, phytotoxicity, and bioavailability data in the literature to estimate precise concentrations in edible parts of the crops.

The results of this study have shown that risk management strategies are needed in the study area and in such areas around the world to protect public health. Even in the lowerbound estimation of Scenario 3, which considers only $10 \%$ consumption from the crops cultivated in the Simav Plain, aggregate non-carcinogenic and carcinogenic risks are significant, and risk mitigation strategies are needed. Wheat, tomato, onion, and cucumber are the species with significant carcinogenic and chronic toxic risks. Therefore, importing only these crops from uncontaminated places would reduce the aggregate risks up to $88 \%$. Since there is no safe level for arsenic, the consumption of produce grown on the plain needs to be minimized until further research on crop-related field data is conducted.

\section{Compliance with ethical standards}

Conflict of interest The authors declare that they have no conflict of interest.

\section{References}

Ahmed MK, Shaheen N, Islam MS, Habibullah-Al-Mamun M, Islam S, Islam MM, Kundu GK, Bhattacharjee L (2016) A comprehensive assessment of arsenic in commonly consumed foodstuffs to evaluate the potential health risk in Bangladesh. Sci Total Environ 544:125133. https://doi.org/10.1016/j.scitotenv.2015.11.133 
Alam MO, Chakraborty S, Bhattacharya T (2016) Soil arsenic availability and transfer to food crops in Sahibganj, India with reference to human health risk. Environ Process 3:763-779. https://doi.org/10. 1007/s40710-016-0184-9

Alexander PD, Alloway BJ, Dourado AM (2006) Genotypic variation in the accumulation of $\mathrm{Cd}, \mathrm{Cu}, \mathrm{Pb}$ and $\mathrm{Zn}$ exhibited by six commonly grown vegetables. Environ Pollut 144:736-745. https://doi.org/10. 1016/j.envpol.2006.03.001

Antoniadis V, Shaheen SM, Boersch J, Frohne T, Du Laing G, Rinklebe J (2017) Bioavailability and risk assessment of potentially toxic elements in garden edible vegetables and soils around a highly contaminated former mining area in Germany. J Environ Manag 186:192200. https://doi.org/10.1016/j.jenvman.2016.04.036

Asante-Duah K (2002) Public health risk assessment for human exposure to chemicals. Springer, Dordrecht

ATSDR (Agency for Toxic Substances and Disease Registry) (2000) Toxicological profile for arsenic. Department of Health and Human Services, Public Health Service, Agency for Toxic Substances and Disease Registry, Atlanta, GA

Bissen M, Frimmel FH (2003) Arsenic - a review. Part I: occurrence, toxicity, speciation, mobility. Acta Hydrochim Hydrobiol 31:9-18. https://doi.org/10.1002/aheh.200390025

Canadian soil quality guidelines (1997) Canadian Council of Ministers of the Environment, Winnipeg, Canada. https://www.ccme.ca/files/ Resources/supporting scientific documents/pn 1268 e.pdf. Accessed 1 August 2018

Dahal BM, Fuerhacker M, Mentler A, Karki K, Shrestha R, Blum W (2008) Arsenic contamination of soils and agricultural plants through irrigation water in Nepal. Environ Pollut 155:157-163. https://doi.org/10.1016/j.envpol.2007.10.024

Dai Y, Lv J, Liu K, Zhao X, Cao Y (2016) Major controlling factors and prediction models for arsenic uptake from soil to wheat plants. Ecotoxicol Environ Saf 130:256-262. https://doi.org/10.1007/ s11368-014-0854-z

Environmental quality standards for soil pollution (n.d.) Ministry of the Environment, Government of Japan, Japan https://www.env.go.jp/ en/water/soil/sp.html Accessed 1 August 2018

Farooq MA, Islam F, Ali B, Najeeb U, Mao B, Gill RA, Zhou W (2016) Arsenic toxicity in plants: cellular and molecular mechanisms of its transport and metabolism. Environ Exp Bot 132:42-52. https://doi. org/10.1016/j.envexpbot.2016.08.004

Gunduz O, Simșek C, Hasözbek A (2010) Arsenic pollution in the groundwater of Simav Plain, Turkey: its impact on water quality and human health. Water Air Soil Poll 205:43-62. https://doi.org/ 10.1007/s11270-009-0055-3

Gunduz O, Elçi A, Șimșek C, Baba A, Bakar C, Gürleyük H (2012) Simav Ovası (Kutahya) Yeraltı Suyunda Arsenik Kirliliğinin Araştırılması ve İnsan Sağlığına Olan Risklerinin Değerlendirilmesi (Final Report). TÜBİTAK Project No 109Y029, Izmir, Turkey (in Turkish)

Gunduz O, Bakar C, Șimșek C, Baba A, Elçi A, Gürleyük H, Mutlu M, Çakır A (2015) Statistical analysis of causes of death (2005-2010) in villages of Simav Plain, Turkey, with high arsenic levels in drinking water supplies. Arch Environ Occup Health 70:35-46. https://doi. org/10.1080/19338244.2013.872076

Gunduz O, Bakar C, Șimşek C, Baba A, Elçi A, Gürleyük H, Mutlu M, Çakır A (2017) The health risk associated with chronic diseases in villages with high arsenic levels in drinking water supplies. Expos Health 9:261-273. https://doi.org/10.1007/s12403-016-0238-2

Güneș A (2010) Simav ovası (eski Simav gölü-Simav) ekolojik özellikleri. MSc Thesis, Dumlupınar University, Kutahya, Turkey (in Turkish)

ITASHY (2005) Regulation on waters intended for human consumption (Rep. No. TS 266). Official Gazette, 17 February 2005, \#25730 (in Turkish)
JECFA (2010) Joint FAO/WHO Expert Committee on Food Additives, 72nd meeting, summary and conclusions. World Health Organization

Jiang Y, Zeng X, Fan X, Chao S, Zhu M, Cao H (2015) Levels of arsenic pollution in daily foodstuffs and soils and its associated human health risk in a town in Jiangsu Province, China. Ecotoxicol Environ Saf 122:198-204. https://doi.org/10.1016/j.ecoenv.2015. 07.018

Jolly YN, Islam A, Akbar S (2013) Transfer of metals from soil to vegetables and possible health risk assessment. Springer Plus 2:385. https://doi.org/10.1186/2193-1801-2-385

Juhasz AL, Herde P, Herde C, Boland J, Smith E (2015) Predicting arsenic relative bioavailability using multiple in vitro assays: validation of in vivo-in vitro correlations. Environ Sci Technol 49:1116711175. https://doi.org/10.1021/acs.est.5b02508

Kabata-Pendias A, Pendias H (2011) Trace elements in soils and plants, 4th edn. CRC Press, Washington, DC

Kar S, Das S, Jean JS, Chakraborty S, Liu CC (2013) Arsenic in the water-soil-plant system and the potential health risks in the coastal part of Chianan Plain, Southwestern Taiwan. J Asian Earth Sci 77: 295-302. https://doi.org/10.1016/j.jseaes.2013.03.003

KGOPDEU (Kutahya Governor's Office Provincial Directorate for Environment and Urbanization) (2011) Kutahya provincial environmental status report. Kutahya, Turkey (in Turkish).https://webdosya. csb.gov.tr/db/ced/editordosya/kutahya_icdr2011.pdf. Accessed 1 Aug 2018

KGOPDEU (Kutahya Governor's Office Provincial Directorate for Environment and Urbanization) (2016) Kutahya provincial environmental status report. Kutahya Turkey (in Turkish). https://webdosya. csb.gov.tr/db/ced/editordosya/kutahya_icdr2016.pdf. Accessed 1 Aug 2018

Khan A, Khan S, Khan MA, Qamar Z, Waqas M (2015) The uptake and bioaccumulation of heavy metals by food plants, their effects on plants nutrients, and associated health risk: a review. Environ Sci Pollut Res 22:13772-13799. https://doi.org/10.1007/s11356-0154881-0

Neidhardt H, Norra S, Tang X, Guo H, Stüben D (2012) Impact of irrigation with high arsenic burdened groundwater on the soil-plant system: results from a case study in the Inner Mongolia, China. Environ Pollut 163:8-13. https://doi.org/10.1016/j.envpol.2011.12. 033

Núñez R, García MA, Alonso J, Melgar MJ (2018) Arsenic, cadmium and lead in fresh and processed tuna marketed in Galicia (NW Spain): risk assessment of dietary exposure. Sci Total Environ 627:322-331. https://doi.org/10.1016/j.scitotenv.2018.01.253

Pizarro I, Gómez-Gómez M, León J, Román D, Palacios M (2016) Bioaccessibility and arsenic speciation in carrots, beets and quinoa from a contaminated area of Chile. Sci Total Environ 565:557-563. https://doi.org/10.1016/j.scitotenv.2016.04.199

Pollution Control Department of Thailand (2001) Water quality standards. http://www.pcd.go.th/. Accessed 1 Aug 2018

Rasheed H, Kay P, Slack R, Gong YY (2018) Arsenic species in wheat, raw and cooked rice: exposure and associated health implications. Sci Total Environ 634:366-373. https://doi.org/10.1016/j.scitotenv. 2018.03.339

Rehman ZU, Khan S, Qin K, Brusseau ML, Shah MT, Din I (2016) Quantification of inorganic arsenic exposure and cancer risk via consumption of vegetables in southern selected districts of Pakistan. Sci Total Environ 550:321-329. https://doi.org/10.1016/ j.scitotenv.2016.01.094

Rosas-Castor JM, Guzman-Mar JL, Alfaro-Barbosa JM, HernándezRamírez A, Pérez-Maldonado IN, Caballero-Quintero A, Hinojosa-Reyes L (2014a) Evaluation of the transfer of soil arsenic to maize crops in suburban areas of San Luis Potosi, Mexico. Sci Total Environ 497-498:153-162. https://doi.org/10.1016/j.scitotenv. 2014.07.072 
Rosas-Castor JM, Guzmán-Mar JL, Hernández-Ramírez A, GarzaGonzález MT, Hinojosa-Reyes L (2014b) Arsenic accumulation in maize crop (Zea mays): a review. Sci Total Environ 488-489:176187. https://doi.org/10.1016/j.scitotenv.2014.04.075

Singh V, Brar MS, Sharma P, Malhi SS (2010) Arsenic in water, soil, and Rice plants in the Indo-Gangetic Plains of northwestern India. Commun Soil Sci Plant Anal 41:1350-1360. https://doi.org/10. 1080/00103621003759353

Sofuoglu SC, Güzelkaya H, Akgül Ö, Kavcar P, Kurucaovalı F, Sofuoglu A (2014) Speciated arsenic concentrations, exposure, and associated health risks for rice and bulgur. Food Chem Toxicol 64:184-191. https://doi.org/10.1016/j.fct.2013.11.029

The World Bank (2017) https://data.worldbank.org/indicator/SP.DYN. LE00.IN?locations $=$ TR\&view=chart. Accessed 27 July 2018

TKKY (2001) Turkey Soil Pollution Control Regulation (Rep. No. TSP 24609). Official Gazette, Dated 10 December 2001, Numbered 24609 (in Turkish)

TSI (Turkish Statistical Institute) (2016) http://www.turkstat.gov.tr/ PreTabloArama.do?metod=search. Accessed 27 July 2018

USEPA (United States Environmental Protection Agency) (2011) Exposure factors handbook 2011 edition. US Environmental Protection Agency, Washington, DC EPA/600/R09/052F

Warren GP, Alloway BJ, Lepp NW, Singh B, Bochereau FJM, Penny C (2003) Field trials to assess the uptake of arsenic by vegetables from contaminated soils and soil remediation with iron oxides. Sci Total Environ 311:19-33. https://doi.org/10.1016/S0048-9697(03)000962

WHO (2001) Environmental health criteria 224: arsenic and arsenic compounds. World Health Organization, Geneva
WHO (2010) Exposure to arsenic: a major public health concern. World Health Organization, Geneva

Woolson EA (1973) Arsenic phytotoxicity and uptake in six vegetable crops. Weed Sci 21:524-527

Yoon Y, Lee WM, An YJ (2015) Phytotoxicity of arsenic compounds on crop plant seedlings. Environ Sci Pollut Res 22:11047-11056. https://doi.org/10.1007/s11356-015-4317-x

Zhang H, Selim HM (2008) Reaction and transport of arsenic in soils: equilibrium and kinetic modeling. Adv Agron 98:45-115. https:// doi.org/10.1016/S0065-2113(08)00202-2

Zhao FJ, Ma JF, Meharg AA, McGrath SP (2009) Arsenic uptake and metabolism in plants. New Phytol 181:777-794. https://doi.org/10. 1111/j.1469-8137.2008.02716.x

Zhao FJ, McGrath SP, Meharg AA (2010) Arsenic as a food chain contaminant: mechanisms of plant uptake and metabolism and mitigation strategies. Annu Rev Plant Biol 61:535-559. https://doi.org/10. 1146/annurev-arplant-042809-112152

Zhu Y-G, Williams PN, Meharg AA (2008) Exposure to inorganic arsenic from rice: a global health issue? Environ Pollut 154:169-171. https://doi.org/10.1016/j.envpol.2008.03.015

Publisher's note Springer Nature remains neutral with regard to jurisdictional claims in published maps and institutional affiliations. 